\title{
HUBUNGAN MOTIVASI, ATTITUDE, ANXIETY DAN SELF EFFICACY TERHADAP PRESTASI ATLET TENIS LAPANGAN LEVEL JUNIOR DAN SENIOR
}

\author{
Abdul Alim \\ Fakultas Ilmu Keolahragaan Universitas Negeri Yogyakarta, Jl. Colombo No. 1, Karangmalang Depok, Sleman, \\ Yogyakarta, Indonesia \\ abdulalim@uny.ac.id
}

\begin{abstract}
Abstrak
Tujuan penelitian ini adalah untuk mengetahui hubungan motivasi, attitude, anxiety, dan self efficacy terhadap prestasi atlet tenis lapangan dan menganalisis perbedaan hubungan antara atlet tenis lapangan pada level junior dan senior. Metode penelitian untuk mengungkapkan masalah tersebuat yaitu melalui metode penelitian deskriptif dengan desain penelitian deskriptif komparatif korelasional. Populasi dalam penelitian ini adalah atlet tenis lapangan tingkat Daerah maupun Nasional di Indonesia. Sampel penelitian ini berjumlah 133 terdiri dari 42 petenis laki-laki junior dan 21 petenis perempuan junior, 44 petenis laki-laki senior, dan 26 petenis perempuan senior. Teknik sampling yang digunakan dalam penelitian ini adalah teknik insidental sampling yang dilakukan dengan cara insidental atau kebetulan saja tidak menggunakan perencanaan tertentu. Penelitian dilakukan pada minggu kedua bulan Februari sampai minggu keempat bulan Juni. Instrumen yang digunakan pada penelitian ini adalah kuesioner. Hasil analisis data dari 133 orang petenis baik junior maupun senior menunjukkan bahwa baik motivasi, self efficacy, attitude, maupun kecemasan tidak memiliki hubungan yang signifikan dengan prestasi.

Kata Kunci : motivasi, attitude, anxiety, self efficacy, prestasi atlet tenis
\end{abstract}

\section{RELATIONSHIP MOTIVATION, ATTITUDE, ANXIETY AND EFFICIENCY OF SELF TO THE ACHIEVEMENT OF TENNIS FIELD JUNIOR AND SENIOR LEVELS}

\begin{abstract}
The purpose of this study was to determine the relationship of motivation, attitude, anxiety, and selfefficacy on the achievements of field tennis athletes and analyze the differences in the relationship between field tennis athletes at the junior and senior levels. The research method to express the problem is through descriptive research method with a comparative descriptive research design. The population in this study are regional and national level tennis athletes in Indonesia. The research sample consisted of 133 consisting of 42 junior male tennis players and 21 junior female tennis players, 44 senior male tennis players, and 26 senior female tennis players. The sampling technique used in this study is incidental sampling technique which is done by incidental or coincidental by not using a particular plan. The study was conducted in the second week of February through the fourth week of June. The instrument used in this study was a questionnaire. The results of data analysis of 133 tennis players, both junior and senior, indicate that neither motivation, self efficacy, attitude, or anxiety do not have a significant relationship with achievement.
\end{abstract}

Keywords: motivation, attitude, anxiety, self efficacy, tennis athlete achievement

\section{PENDAHULUAN}

Beberapa tahun terakhir ini, secara umum prestasi tenis lapangan Indonesia mengalami penurunan. Hal ini pun diakui oleh beberapa pelatih dan atlet tenis lapangan. Dalam wawancaranya dengan RRI, Bonit Wiryawan yang merupakan mantan atlet tenis nasional 
mengungkapkan bahwa prestasi tenis lapangan Indonesia mengalami penurunan. Prestasi puncak olahraga tenis lapangan Indonesia terakhir dicapai pada penyelenggaran ajang Sea Games 2011 Jakarta Palembang dengan perolehan 4 medali emas. Setelah itu tim tenis lapangan Indonesia puasa medali emas. Pada Sea Games 2015 yang diselenggarakan di Singapura, tim tenis lapangan Indonesia tidak satupun berhasil memperoleh 1 medali emas. Pahahal, pada penyelengaraan-penyelenggaraan sebelumnya, minimal Indonesia bisa menyabet 1 medali emas. Pelatih tenis nasional Dedi Prasetyo pun juga mengungkapkan bahwa prestasi tenis Indonesia mengalami penurunan.

Berbicara mengenai pencapaian prestasi dalam bidang olahraga, tentunya pencapaian prestasi tersebut merupakan proses yang kompleks. Banyak faktor yang perlu diperhatikan dan dilatih untuk mencapai prestasi yang optimal. Faktor yang mempengaruhi pencapaian prestasi di antaranya kondisi fisik/ biomotor, kemampuan penguasaan teknik dan taktik, serta faktor psikologikal. Pendapat lain dari Ihsan Sari (2015: 675) menjelaskan bahwa pencapaian prestasi yang optimal dipengaruhi oleh faktor fisiologi (kondisi fisik/biomotor), penguasaan gerak (teknik), nutrisi, dan psikologis atlet. Keseluruhan faktor tersebut saling mendukung satu sama lain dalam pencapaian peforma yang optimal. Para pakar olahraga setuju bahwa pencapaian performa yang optimal dapat dicapai tidak hanya karena pengaruh keterampilan fisik semata tetapi juga dipengaruhi oleh faktor psikologikal (Kenioua \& Boumesjed, 2017: 36).

Kualitas latihan yang diterapkan sejak level junior sangat mempengaruhi keberhasilan dalam pencapaipan prestasi. Penerapan latihan yang disesuaikan dengan kebutuhan cabor dan individu, serta latihan yang mencakup segala aspek pendukung pencapaian prestasi akan dapat menjadikan proses latihan tersebut berkualitas. Fakta di lapangan menunjukkan bahwa kecenderungan pelatih masih menitik beratkan pada pelatihan fisik dan latihan teknik taktik. Latihan mental/ psikologikal juga diterapkan tetapi masih mendapatkan porsi yang sedikit atau kurang tepat, sehingga hasil latihan kurang maksimal.

Pengetahuan mengenai faktor-faktor yang mempengaruhi pencapaian performa atau prestasi puncak sangat diperlukan oleh pelatih maupun atlet itu sendiri. Kesadaran akan pentingnya faktor psikologis diperlukan agar dapat memperbaiki dan meningkatkan kemampuan psikologis sebagai faktor pendukung tercapainya prestasi puncak. Hal ini diperkuat dengan hasil penelitian yang telah dilakukan oleh Baker \& Sedwick tahun 2005 dalam Heazlewood \& Burke (2011: 1) yang mengungkapkan bahwa faktor psikologikal dalam olahraga teridentifikasi sebagai faktor penting dalam meningkatkan performa.

Motivasi, attitude, dan self efficacy serta anxiety merupakan beberapa faktor psikologi yang dapat mempengaruhi prestasi seorang atlet. Motivasi adalah sebuah terminologi yang sangat 'terkenal' dan cenderung menjadi salah satu kata kunci yang terutama apabila membahas mengenai kesuksesan di berbagai macam aspek kehidupan, seperti kesuksesan dalam bisnis dan tentu saja dalam hal ini, olahraga. Seberapa termotivasinya seorang atlet dapat dilihat dari arah dan intensitas usaha yang dilakukan oleh atlet tersebut (Sage, 1977). Tiga elemen utama dalam definisi motivasi di antaranya adalah intensitas, arah, dan ketekunan. Dalam hubungan antara motivasi dan intensitas, intensitas terkait dengan seberapa giat seseorang berusaha, tetapi intensitas tinggi tidak menghasilkan prestasi kerja yang memuaskan kecuali upaya tersebut dikaitkan dengan arah yang menguntungkan organisasi. Sebaliknya elemen yang terakhir, ketekunan, merupakan ukuran mengenai berapa lama seseorang dapat mempertahankan usahanya. Motivasi dalam olahraga merupakan sesuatu dorongan yang dimiliki seseorang untuk berolahraga. Cucui I. A. \& Cucui G.G. (2014: 67) menyatakan bahwa terdapat dua macan motivasi yaitu motivasi intrinsik dan motivasi ekstrinsik.

Motivasi intrinsik adalah dorongan dari dalam yang menyebabkan individu berpartisipasi. Dorongan ini sering dikatakan dibawa sejak lahir, sehingga tidak dapat dipelajari. Kilpatrick et al (2015) menyatakan bahwa partisipasi dalam olahraga lebih dekat 


\section{MEDIKORA, Vol. XVII No. 2 Oktober 2018 - 85}

Abdul Alim

hubungannya dengan motivasi intrinsik, sedangkan exercise dihubungkan dengan motivasi ekstrinsik.

Pelliter et al dalam Heerden (2014: 67) menyataan bahwa terdapat tiga dimensi dalam motivasi internal yaitu: 1) motivation to know, 2) motivation to accomplish, dan 3) motivation to stimulation. Motivasi untuk mengetahui mengarah pada pemenuhan kebutuhan pengalaman dalam belajar dan usaha memahami konsep baru dalam partisipasi olahraga. Motivasi untuk pencapaian didefinisikan sebagai keterlibatan dalam suatu kegiatan untuk kesenangan dan kepuasan seseorang dalam mencapai tujuan pribadi, sedangkan seseorang yang dimotivasi akan mengalami stimulasi untuk berpartisipasi untuk tujuan mendapatkan pengalaman dengan sensasi yang berbeda. Weinberg \& Gould dalam (Cucui I. A. \& Cucui G.G. (2014: 69) menyatakan bahwa terdapat 3 teori motivasi yaitu: 1) the need for achievement theory, 2) the attribution theory dan 3) the goal attainment theory. Teori kebutuhan prestasi mempertimbangkan bahwa motivasi berprestasi dipengaruhi oleh faktor kepribadian, situasional, tren, reaksi emosional, dan perilaku berprestasi sebagai akibat dari interaksi faktor kepribadian, situasional, tren dan reaksi emosional. Teori atribusi mengacu pada proses kognitif dimana individu mempresepsikan dan menjelaskan perilaku sendiri atau perilaku orang lain dalam kehidupan sehari-hari. Teori atribusi berkaitan dengan suatu keadaan yang dihubungakan dengan kesuksesan atau kegagalan dalam suatu aktivitas Teori pencapaian tujuan berkaitan dengan dorongan seseorang untuk melakukan sesuatu guna mencapai tujuan tertentu.

Motivasi ekstrinsik adalah dorongan yang berasal dari luar diri individu yang menyebabkan individu beradaptasi dalam olahraga (Karel Muskanan, 2015: 108). Dorongan ini barasal dari pelatih, guru, orang tua, bangsa atau berupa hadiah, sertifikat, penghargaan atau uang. Heerden (2014: 67) menyatakan bahwa motivasi ekstrinsik dalam olahraga merupakan dorongan dari luar untuk berpartisipasi pada suatu aktivitas atau kegiatan olahraga untuk mendapatkan kesengangan maupun hadiah atau menghindari hukuman. Motivasi ekstrinsik itu dapat dipelajari dan tergantung pada besarnya nilai penguat itu dari waktu ke waktu. Motivasi ekstrinsik biasa didefinisikan motivasi yang datang dari luar individu. Dengan kata lain, motivasi yang dimiliki seseorang tersebut dikendalikan oleh objek-objek yang berasal dari luar individu. Contoh-contoh motivasi yang bersifat ekstrinsik adalah: hadiah, trofi, uang, pujian, dan sebagainya.

Attitude merupakan seperangkat ciri atau karakteristik yang relatif menetap dan terorganisasikan dalam diri individu yang mempengaruhi tingkah laku individu tersebut. Attitude merupakan salah satu faktor yang dapat mempengaruhi kesuksesan seorang atlet dalam olahraga. Attitude menginginkan stabilitas dan perubahan. Aspek stabilitas memberikan struktur yang diperlukan untuk berfungsi secara efektif dalam masyarakat, sedangkan aspekaspek yang bersifat dinamis dan berubah-ubah memberikan kesempatan untuk belajar. Attitude atau sikap didefinisikan sebagai kondisi kesiapan mental atau saraf yang diorganisasikan oleh pengalaman, pemberian suatu arahan atau pengaruh dinamis pada respon individu terhadap seluruh objek dan situasi terkait (Allport dalam Borkowski, 2005: 44). Definisi sederhana dari sikap adalah kecenderungan seseorang dalam bertindak dengan cara tertentu berdasarkan pengalaman individu. Borkowski, 2005: 44) menyatakan bahwa attitude termasuk suatu hal yang kompleks yang merupakan kombinasi dari kepribadian, kepercayaan, nilai, kebiasaan dan motivasi. Attitude memiliki 3 komponen, meliputi: a) an affect (a feeling), b) cognition ( $a$ thought/ belief), dan c) behavior (an action). 


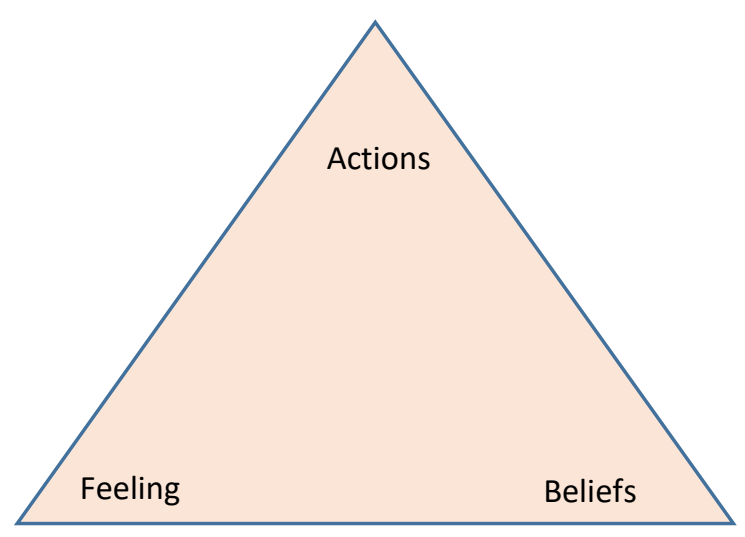

Gambar 1. Komponen Attitude

(Borkowski, 2005: 45)

Tiga komponen attitude tersebut dikenal dengan sebutan model triadic attitude. Komponen beliefs atau kepercayaan mengacu pada aspek kognitif seseorang yang berhubungan dengan pengetahuan, sebagai contoh seseorang yang percaya bahwa olahraga jogging dapat meningkatkan efisiensi kardiovaskular. Komponen berikutnya adalah feeling yang mengacu atau berkaitan dengan aspek emosional seseorang, sebagai contoh jogging dimungkinkan dapat meningkatkan sikap seseorang karena tubuh mengeluarkan endorphins selama aktivitas, dan mengakibatkan perasaan bahagia atau perasaan baik pada diri seseorang tersebut. Komponen terakhir adalah actions yang mengacu pada respon komponen sikap seseorang. Apabila beliefs (kepercayaan) dan feeling (emosional) seseorang baik maka action (respon) seseorang tersebut juga baik, sebagai contoh seseorang yang percaya bahwa jogging dapat meningkatkan efisiensi kardiovaskular dan kemudian melakukan jogging serta merasakan manfaatnya, seseorang tersebut akan terus melakukan jogging karena mendapatkan manfaat dari melakukan jogging.

Menurut Weinberg dan Gould (2007: 78) kecemasan atau anxienty merupakan sebuah perasaan negatif yang memiliki ciri gugup, rasa gelisah, ketakutan akan sesuatu yang akan terjadi, dan yang terjadi pergerakan atau kegairahan dalam tubuhBanyak ahli menyatakan bahwa kecemasan termasuk ke dalam emosional negatif (Raglin \& Hanin, 2000; Juuso, 2011: 7; Parnabas, Mahamood, Parnabas, 2013: 61; Kahn et al, 2017: 2; Sallayici et al, 2018: 10;). Atikinson (1983: 212) menyatakan kecemasan adalah emosi yang tidak menyenangkan yang ditandai dengan gejala-gejala seperti khawatir, keprihatinan dan rasa takut yang dialami pada tingkat dan kondisi yang berbeda-beda. Khan et al (2017: 5) menyebutkan bahwa kecemasan adalah reaksi natural pada diri seseorang yang melibatkan pikiran dan tubuh yang merupakan sistem alarm yang aktif ketika seseorang merasakan suatu bahaya atau ancaman. Dapat disimpulkan bahwa kecemasan merupakan gejala psikologis yang ditandai dengan rasa khawatir, gugup, rasa gelisah, ketakutan yang dialami seseorang pada tingkat dan kondisi yang berbedabeda ketika merasakan suatu bahaya atau ancaman.

Kecemasan dapat dideteksi dengan melihat gejala-gejala yang timbul. Untuk mendeteksi tingkat kecemasan seseorang secara akurat diharuskan mengetahui berbagai macam gejala peningkatan kecemasan. Gejala kecemasan yang dapat dijadikan indikator seseorang mengalami kecemasan dapat dilihat dari gejala perubahan fisik, psikis maupun perilaku. Gejala secara fisik merupakan perubahan akibat aktivasi fisiologis pada seseorang yang mengalami kecemasan. Gejala fisik tersebut di antaranya: tangan menjadi dingin, meningkatnya frekuensi buang air kecil, berkeringat, berkunang-kunang, mulut kering, sakit perut, denyut nadi meningkat. Gejala secara psikis merupakan gejala kecemasan yang dapat dilihat dari perubahan psikis seseorang akibat kecemasan. Gejala psikis tersebut di antaranya perhatian dan konsentrasi yang berkurang, menurunnya rasa percaya diri, gugup, khawatir. Selain gejala fisik dan psikis pada kecemasan terdapat gejala perilaku yaitu gejala kecemasan yang dapat dilihat berdasarkan perubahan pada perilaku seseorang yang mengalami kecemasan. Gejala tersebut di antaranya: menggigit kuku jari, perubahan raut muka, menjadi pendiam atau banyak bicara, menggerakkan atau menggoyanggoyangkan kaki. Stephani Yane (2013: 190) menyebutkan bahwa terdapan tiga tingkatan gejala pada seseorang yaitu: 1) gejala kognitif yang berkaitan dengan proses berpikir, termasuk berkurangnya rasa 


\section{MEDIKORA, Vol. XVII No. 2 Oktober 2018 - 87}

Abdul Alim

percaya diri, berkurangnya konsentrasi, rasa taku, 2) gejala somatik, seperti gejala berkeringat pada tangan dan kaki, peningkatan denyut jantung, serta ketegangan otot, 3) gejala perilaku, seperti menggigit kuku, menghindari kontak mata dengan orang lain, dan menyendiri.

Selanjutnya, Self efficacy merupakan suatu faktor psikologis yang memiliki perbedaan makna dengan self confidence. Menurut Bandura (dalam Feist \& Feist, 2008) self efficacy harus di lihat dari beberapa konsep, pertama self efficacy tidak mengacu kepada penilaian kemampuan motorik dasar seperti berjalan, berjabat tangan, atau memeluk, kedua self efficacy tidak berarti kita dapat melakukan perilaku yang diinginkan tanpa kecemasan, tekanan, atau rasa takut, tidak lebih dari sebuah penilaian, akurat, atau keliru, tentang apakah kita dapat atau tidak menilai tindakan yang dibutuhkan, ketiga self efficacy tidak sama dengan aspirasi. Singh, Bhardwaj, \& Bhardwaj (2009: 110) menyatakan bahwa self efficacy merupakan kepercayaan orang pada kemampuan mereka untuk untuk menampilkan sesuatu sesuai dengan kemampuannya yang memberikan mereka kendali atas kejadian atau peristiwa yang mempengaruhi kehidupannya. Alwisol (2009) self-efficacy merupakan orang yang memiliki efikasi yang realistik (apa yang diharapkan sesuai dengan keyataan hasil), atau sebaliknya efikasi hasilnya tidak realistik (mengharap terlalu tinggi dari hasil nyata yang dapat dicapai), orang yang ekspektasi efikasinya tinggi (percaya bahwa dia dapat mengerjakan sesuai dengan tututan situasi) dan harapan hasilnya realistik (memperkirakan hasil sesuai dengan kemampuan diri), orang itu akan bekerja keras dan bertahan mengerjakan tugas sampai selesai. Self efficacy, adalah penilaian diri apakah dapat melakukan tindakan yang baik atau buruk, tepat atau salah, bisa atau tidak bisa mengerjakan sesuai dengan yang disyaratkan. Dengan memiliki motivasi, attitude, dan self efficacy yang baik serta anxiety yang rendah, seorang atlet akan dapat meraih prestasi yang optimal. Kondisi fisik dan kemampuan teknik taktik yang didukung dengan kemampuan psikologis yang mumpuni akan mendukung setiap atlet untuk mencapai prestasi.

Penelitian lebih lanjut mengenai faktor-faktor psikologis yang lebih spesifik mempengaruhi pencapaian prestasi yang optimal diperlukan sebagai upaya ilmiah untuk mengetahui faktor-faktor psikologis yang berpengaruh pada pencapaian prestasi tersebut khususnya pada cabang olahraga tenis lapangan. Penelitian ini bertujuan untuk mengetahui hubungan dan menganalisis perbedaan antara motivasi, attitudes, anxiety, dan self efficacy terhadap prestasi atlet tenis. Berdasarkan latar belakang yang telah dipaparkan maka, teridentifikasi beberapa masalah yang menjadi fokus dalam penelitian ini, yaitu : 1) Prestasi tenis Indonesia mengalami penurunan dalam beberapa tahun terakhir ini. 2) Faktor psikologis belum mendapatkan porsi yang semestinya dalam penerapan latihan. 3) Belum diketahuinya hubungan faktor-faktor psikologis (motivasi, attitude, anxiety, dan self efficacy) terhadap prestasi atlet tenis. 4) Belum diketahuinya perbedaan hubungan motivasi, attitude, anxiety, dan self efficacy terhadap prestasi tingkat daerah dan nasional pada atlet junior dan senior.

Berdasarkan paparan diatas maka penelitian ini bertujuan untuk :1) Mengetahui dan menganalisis hubungan motivasi terhadap prestasi atlet tenis lapangan? 2) Mengetahui dan menganalisis hubungan attitude terhadap prestasi atlet tenis lapangan? 3) Mengetahui dan menganalisis hubungan anxiety terhadap prestasi atlet tenis lapangan? 4) Mengetahui dan menganalisis hubungan self efficacy terhadap prestasi atlet tenis lapangan?

\section{METODE}

Penelitian ini merupakan penelitian korelasional. Jika dikaitkan dengan substansinya, peneliti ingin mengetahui bagaimana hubungan antara motivasi, attitude, anxiety, dan selfefficacy terhadap prestasi atlet tenis lapangan junior dan senior. Populasi dalam penelitian ini adalah atlet tenis lapangan junior dan senior pada tingkat daerah maupun nasional di Indonesia. Sampel penelitian ini berjumlah 133 terdiri dari 42 petenis laki-laki junior dan 21 petenis perempuan junior, 44 petenis laki-laki senior, dan 26 petenis perempuan senior. Teknik sampling yang digunakan dalam penelitian ini adalah teknik insidental sampling yang dilakukan dengan cara insidental atau kebetulan saja tidak menggunakan perencanaan tertentu.

Penelitian dilakukan pada minggu kedua bulan februari sampai minggu keempat bulan Juni. Pengambilan data penelitian akan dilakukan pada event-event kejuaraan tenis baik kejuaraan tenis daerah maupun nasional, junior dan senior. Instrumen yang digunakan pada penelitian ini adalah kuesioner. Terdapat empat kuesioner yang nantinya digunakan untuk mendapatkan data penelitian. Kuesioner tersebut yaitu: 1) Kuesioner Motivasi, 2) kuesioner attitude, 3) kuesioner anxiety, dan 4) kuesioner self efficacy. Setiap pertanyaan/ pernyataan 
yang ada pada kuesioner tersebut akan mewakili setiap indikator variabel yang telah ditentukan. Pengukuruan variable dalam kuesioner akan diukur menggunakan skala likert 1-5.

\section{HASIL DAN PEMBAHASAN}

Dalam penelitian ini membahas mengenai hubungan motivasi, self efficacy, attitude dan kecemasan pada prestasi atlet tenis baik petenis junior maupun senior. Penjabaran analisis data penelitian ini dideskripsikan menjadi dua bagian yaitu pada petenis junior dan petenis senior. Hasil analisis korelasi antara motivasi, self efficacy, attitude dan kecemasan terhadap prestasi atlet tenis junior dapat dilihat pada tabel berikut:

Tabel 1. Hasil Analisis Korelasi Motivasi, self efficacy, attitude dan kecemasan terhadap Prestasi Atlet Tenis Junior.

\begin{tabular}{lcc}
\hline \multicolumn{1}{c}{ Variabel } & $R$ & P Value \\
\hline Level Petenis*Motivasi & .117 & 0,360 \\
Level Petenis*Self Efficacy & .227 & 0,073 \\
Level Petenis*Atitude & .156 & 0,221 \\
Level Petenis*Kecemasan & .079 & 0,541 \\
\hline
\end{tabular}

Tabel 1. menunjukkan hubungan antara motivasi, self efficacy, attitude dan kecemasan terhadap Prestasi Atlet Tenis Junior. Data di atas menunjukkan bahwa dari semua variabel yang ada yaitu motivasi, self efficacy, attitude dan kecemasan, kesemuanya tidak memiliki hubungan yang signifikan dengan prestasi tenis atlet junior. Namun demikian dapat kita lihat persentase pengaruh masing-masing variabel dari besaran nilai $r$. Pada motivasi dapat kita lihat nilai $\mathrm{r}$ yaitu 0.117 hal ini berarti motivasi memiliki pengaruh sebesar $11,7 \%$ terhadap prestasi. Pada self efficacy dapat kita lihat nilai $r$ yaitu 0.227 hal ini berarti motivasi memiliki pengaruh sebesar $22,7 \%$ terhadap prestasi. Pada attitude dapat kita lihat nilai r yaitu 0.156 hal ini berarti attitude memiliki pengaruh sebesar $15,6 \%$ terhadap prestasi. Pada kecemasan dapat kita lihat nilai r yaitu 0.079 hal ini berarti kecemasan memiliki pengaruh sebesar 7,9\% terhadap prestasi.

Tabel 2. Hasil Analisis Korelasi Motivasi, self efficacy, attitude dan kecemasan terhadap Prestasi Atlet Tenis Senior

\begin{tabular}{lcc}
\hline \multicolumn{1}{c}{ Variabel } & $R$ & P Value \\
\hline Level Petenis*Motivasi & .112 & 0,315 \\
Level Petenis*Self Efficacy & .134 & 0,269 \\
Level Petenis*Atitude & .045 & 0,710 \\
Level Petenis*Kecemasan & .110 & 0,363 \\
\hline
\end{tabular}

Tabel 2. menunjukkan hubungan antara motivasi, self efficacy, attitude dan kecemasan terhadap Prestasi Atlet Tenis Senior. Data di atas menunjukkan bahwa dari semua variabel yang ada yaitu motivasi, self efficacy, attitude dan kecemasan, kesemuanya tidak memiliki hubungan yang signifikan dengan prestasi tenis atlet junior. Namun demikian dapat kita lihat persentase pengaruh masing-masing variabel dari besaran nilai $r$. Pada motivasi dapat kita lihat nilai $r$ yaitu 0.112 hal ini berarti motivasi memiliki pengaruh sebesar $11,2 \%$ terhadap prestasi. Pada self efficacy dapat kita lihat nilai $r$ yaitu 0.134 hal ini berarti motivasi memiliki pengaruh sebesar 13,4\% terhadap prestasi. Pada attitude dapat kita lihat nilai $r$ yaitu 0.045 hal ini berarti motivasi memiliki pengaruh sebesar $4,5 \%$ terhadap prestasi. Pada kecemasan dapat kita lihat nilai $r$ yaitu 0.110 hal ini berarti kecemasan memiliki pengaruh sebesar $11 \%$ terhadap prestasi. 


\section{MEDIKORA, Vol. XVII No. 2 Oktober 2018 - 89}

Abdul Alim

Hasil analisis data dari 133 orang petenis baik junior maupun senior menunjukkan bahwa baik motivasi, self efficacy, attitude, maupun kecemasan tidak memiliki hubungan yang signifikan dengan prestasi. Psikologis seseorang atlet khususnya atlet tenis dipengaruhi oleh pengalaman bertanding. Semakin sering atau banyak bertanding kondisi psikologisnya akan lebih terlatih.

Pada hasil analisis data dinyatakan bahwa keseluruhan variabel tidak memiliki hubungan yang signifikan terhadap prestasi. Namun, kita masih bisa melihat besaran pengaruh masing-masing variabel. Dapat kita lihat baik pada petenis junior maupun senior, self efficacy merupakan faktor psikologis yang memiliki pengaruh paling besar dibanding faktor lainnya, yaitu motivasi, attitude, dan kecemasan. Level bermain seseorang petenis akan berpengaruh pada emosional atau psikologisnya. Semakin tinggi level petenis maka psikologinya akan semakin baik. Petenis yang sering bertanding akan memiliki selfeffecacy yang baik. Kepercayaan diri petenis akan tumbuh berjalan sesuai dengan banyaknya pertandingan yang petenis tersebut lalui.

\section{SIMPULAN}

Hasil penelitian menunjukkan bahwa motivasi, attitude, selfefficacy dan kecemasan atlet tidak signifikan berpengaruh pada prestasi atlet karena dalam pencapaian prestasi kaitannya dengan faktor psikologis merupakan hal yang sangat kompleks. Pencapaian prestasi dipengaruhi oleh faktor psikologi secara bersamaan, sehingga keempat faktor psikogis tersebut secara tersendiri tidak dapat signifikan mempengaruhi prestasi seseorang.

\section{DAFTAR PUSTAKA}

Alwisol. 2009. Psikologi Kepribadian. Malang: UMM Press.

Borkowski, N. 2005. Organizational behavior in health care. Sudbury: Jones and Bartlett Publishers.

Cucui, I.A. \& Cucui G.G. 2014. Motivation and its implications in sports performance. Civilization and Sport, 15 (1): 67-71.

Feist, J., \& Feist, G. J. 2008. Theories of Personality, 7th edition. McGraw-Hill Companies inc.

Heazlewood \& Burke. 2011. Self efficacy and its relationship to selected sport psychological constructs in the prediction of performance in ironman triathlon. Journal of Human Sport \& Exercise, 6(2): $1-23$.

Heerden, V. 2014. The relationships between motivation type and sport participation among students in a south African context. Journal of Physical Education and Sport Management, 5 (6): 66-71.

Ihsan Sari. 2015. An investigation of imagery, intrinsic motivation, self efficacy and performance in athletes. Anthropologist Journal, 20 (3): 675-688.

Juuso, M. 2011. Self-esteem, anxiety and motivation-the effect of psychological factors on sport performance. Bachelor Thesis. HAAGA-HELIA University.

Karel Muskanan. 2015. Analisis motivasi berprestasi atlet pusat pendidikan dan latihan olahraga pelajar (PPLP) Provinsi Nusa Tengagara Timur. Jurnal Kebijakan \& Administrasi Publik, 19(2): 105113.

Kenioua, M. \& Boumesjed. 2017. The relationship between self efficacy, achievement motivation and state anxiety among football player. Revue Sciences et Pratiques des Activities Physiques Sportives et Artistiques Journal, 11 (1): 36-49.

Khan, et al. 2017. Effect of anxiety on athletic performance. Research \& Investigations in Sports Medicine, 1(1): 1-5.

Kilpatrick EH, Hebert E, Bartholomew J (2005). College students' motivation for physical activity: differentiating men's and women's motives for sport participation and exercise. J. Am. College Health, 54(2): 87-94.

Parnabas, V.A., Mahamood, Y., Parnabas, J. 2013. The relationship between cognitive and somatic anxiety on performance of student-athletes of Universiti Malaysia Perlis (UNIMAP). Sport and Art Journal, 1(3): 61-66.

Raglin, J.S. \& Hanin, Y.L. 2000. Competitive anxiety. In Yuri, L.H., Emotions in Sport (p. 93-111). Champaign, IL: Human Kinetics. 
MEDIKORA, Vol. XVII No. 2 Oktober 2018 - 90

Abdul Alim

Sallayici, et al. 2018. Examination of athletes'anxiety, motivation, imagination value in competitions with different severity level. Asian Journal of Education and Training, 4(1): 9-12).

Singh, T.D, Bhardwaj, \& Bhardwaj, V. 2009. Effect of self-efficacy on the performance of athletes. Journal of Exercise Science and Physiotherapy, 5(2): 110-114.

Weinberg, Robet S. and Gould, Daniel. 2007. Foundations of sport and exercise psychology. United States: Human Kinetics. 